\title{
Effect of hypertension on bacteria composition of prostate biopsy in patients with benign prostatic hyperplasia and prostate cancer in PSA grey-zone
}

\author{
XIAOFENG NI ${ }^{1}$, HONGZHOU MENG ${ }^{2}$, FENG ZHOU ${ }^{2}$, HAINING YU ${ }^{3}$, \\ JIANJIAN XIANG ${ }^{4}$ and SHENGRONG SHEN ${ }^{1}$
}

\begin{abstract}
${ }^{1}$ Department of Food Science and Nutrition, School of Biosystems Engineering and Food Science, Zhejiang University, Hangzhou, Zhejiang 310058; ${ }^{2}$ Department of Urology, The First Affiliated Hospital, Zhejiang University School of Medicine, Hangzhou, Zhejiang 310003; ${ }^{3}$ College of Pharmaceutical Sciences, Zhejiang University of Technology, Hangzhou, Zhejiang 310014; ${ }^{4}$ Department of Ultrasonography, The First Affiliated Hospital, Zhejiang University School of Medicine, Hangzhou, Zhejiang 310003, P.R. China
\end{abstract}

Received February 26, 2016; Accepted April 4, 2016

DOI: $10.3892 /$ br.2016.655

\begin{abstract}
Diagnostic prostate cancer (PC) is difficult to diagnose by prostate biopsy, even in patients with markedly elevated PSA levels. Therefore, we aimed to identify a new, better technique to detect $\mathrm{PC}$ in a more consistent manner. A variety of steps were employed to validate this proposed method, including DNA extraction, polymerase chain reaction (PCR) amplification, denaturing gradient gel electrophoresis (DGGE) and DGGE band sequencing. Four transperineal prostate biopsy specimens were obtained from male patients. The patients were under the age of 65 and PSA levels were 4-10 $\mathrm{ng} / \mathrm{ml}$. We also investigated the bacteria composition of transperineal prostate biopsy in patients with benign prostatic hyperplasia (BPH) and PC by PCR-DGGE profiling. Sequences from selected bands 2 and 4 both matched with Sphingomonas, which is present in lower amounts in PC without hypertension as compared to PC with hypertension, while there were no particular differences in the BPH group. Specific bacteria from the prostate biopsy tissues provide further confidence in PC diagnosis based on a PCR approach as a diagnostic tool, while hypertension was found to be a disturbing factor that can affect the diagnosis of BPH and PC in grey-zone.
\end{abstract}

\section{Introduction}

Prostate cancer (PC) is one of the most common cancer types inflicting men, only second to cutaneous cancer, and

Correspondence to: Professor Shengrong Shen, Department of Food Science and Nutrition, School of Biosystems Engineering and Food Science, Zhejiang University, 866 Yuhangtang Road, Hangzhou, Zhejiang 310058, P.R. China

E-mail: shrshen@zju.edu.cn

Key words: prostate biopsy, benign prostatic hyperplasia, prostate cancer, hypertension, polymerase chain reaction-denaturing gradient gel electrophoresis the second leading cause of cancer-related mortalities for men (1). In 2014, an estimated number of 233,000 men were diagnosed with PC and 29,480 men succumbed to the disease in the USA (2). This indicated the need to further investigate PC.

Hypertension is the largest attributable risk factor for mortality worldwide (3), and is responsible for $>50 \%$ of stroke and coronary heart disease (CHD). The risk factors of hypertension include sedentary lifestyle, stress, visceral obesity, potassium deficiency, obesity, salt sensitivity, alcohol intake and vitamin D deficiency (4). Previous studies suggested that men with hypertension are more likely to be diagnosed with PC than those without hypertension (5). However, the number of studies exploring the correlation between hypertension and $\mathrm{PC}$ risk are rather limited. Han et al and Takeshita et al considered that high blood pressure is positively associated with concurrent serum PSA levels $(6,7)$.

Previous findings showed that the microbial population in EPS, urine and seminal fluid between the subjects with $\mathrm{PC}$ and benign prostatic hyperplasia (BPH) are significantly different, indicating a correlation between PC with urinary microbiota (8).

A small number of investigations regarding the relationship between hypertension and intestinal bacteria have been conducted whereas few studies focus on the effect of hypertension on prostate. A hypothesis was posited in the present study that hypertension can affect the intestinal bacteria of PC.

Use of traditional culture methods does not allow for detection of many anaerobic bacteria present in various human body fluids and tissues $(9,10)$. The $16 \mathrm{~S}$ rDNA-based polymerase chain reaction (PCR) is more sensitive than the traditional PCR, depending on microbial culture techniques $(11,12)$. Bacterial species are identified by generating clone libraries of the $16 \mathrm{~S}$ rDNA followed by sequencing and comparison with databases containing thousands of ribosomal sequences $(13,14)$. This method has previously utilized by researchers to evaluate bacterial $16 \mathrm{~S}$ rDNA sequences in prostatic tissue from patients with PC (15-17). 
The aim of the present study was to compare the bacterial composition in the biopsy of PC patients in PSA grey-zone with hypertension with that of the patients without hypertension by PCR-denaturing gradient gel electrophoresis (DGGE) with 16S rDNA methods.

\section{Materials and methods}

Sample collection. Four biopsy samples were collected from male patients diagnosed with PC in the First Affiliated Hospital of Medical School of Zhejiang University (Zhejiang, China). An ultrasound-guided instrument was used to obtain transperineal prostate biopsies. All the patients included in the study were under the age of 65 and the tPSA levels were 4-10 ng/ml. Four samples were selected from 37 patients and divided into two groups: i) patients with PC (with and without hypertension); and ii) patients with $\mathrm{BPH}$ (with and without hypertension). The prostate biopsy samples were placed in sterile centrifuge tubes and stored at $-80^{\circ} \mathrm{C}$ prior to use.

Procedures performed in studies involving human participants were in accordance with the Ethical Standards of the Institutional and/or National Research Committee and with the 1964 Helsinki Declaration and its later amendments or comparable ethical standards. Informed consent was obtained from all individual participants included in the study.

DNA extraction. Total genomic DNA was isolated from the biopsy samples according to the instructions of the QIAamp ${ }^{\circledR}$ DNA mini kit (Qiagen, Hilden, Germany). The extracted DNA was packed into three tubes to avoid multi-gelation and stored at $-20^{\circ} \mathrm{C}$.

PCR amplification. Each DNA sample used in this study was first amplified with universal bacterial primers. The forward primer 341 (5'-GTATTACCGCGGCTGCTGG-3') containing a 40-bp GC clamp (5'-CGCCCGCCGCGCGCGGCGGGCG GGGCGGGGGCACGGGGGG-3') and the reverse primer 534 (5'-ACTCCTACGGGAGGCAGCAG-3') resulted in fragments of approximately $200 \mathrm{bp}$ to test the quality of the template and to exlude the presence of PCR inhibitors. The GC clamp increased the sensitivity of the DGGE analysis (18). The total PCR reaction volume was $50 \mu \mathrm{l}$. The PCR mixture comprised $1 \mu \mathrm{l}$ of Bestar Taq DNA polymerase $(2.5 \mathrm{U} / \mu \mathrm{l}), 5 \mu \mathrm{l}$ of deoxynucleoside triphosphates (dNTPs, $2 \mathrm{mM}$ each), $5 \mu 1$ of $10 \mathrm{X}$ Bestar Taq buffer (all from DBI Bioscience, Shanghai, China), $1 \mu \mathrm{l}$ of each primer (10 $\mu \mathrm{M}$; Sangon, Shanghai, China) and $2 \mu \mathrm{l}$ of extracted bacterial DNA ( $\sim 00 \mathrm{ng})$. The thermal cycling program was set at $94^{\circ} \mathrm{C}$ for $5 \mathrm{~min}$, with 35 cycles of touchdown PCR denaturation at $94^{\circ} \mathrm{C}$ for $30 \mathrm{sec}$, annealing at $60^{\circ} \mathrm{C}$ for $30 \mathrm{sec}$, and $72^{\circ} \mathrm{C}$ extension for $30 \mathrm{sec}$ and a final extension at $72^{\circ} \mathrm{C}$ for $5 \mathrm{~min}$, prior to incubation at $4^{\circ} \mathrm{C}$.

PCR products were tested by electrophoresis on $1.0 \%$ (w/v) agarose gel. Electrophoresis was performed at $100 \mathrm{~V}$ for 20 min with 1X TAE buffer, and visualized by ethidium bromide staining using a gel imaging system (JS-780; Pei Qing Technology Co., Ltd., Shanghai, China). PCR products were stored at $-20^{\circ} \mathrm{C}$ prior to DGGE electrophoresis.

DGGE electrophoresis. DNA fragments with different sequences were separated in $8 \%$ polyacrylamide
Table I. Characteristics of patients with PC groups.

\begin{tabular}{lccll}
\hline Group & Number & PSA (T/F) & Diagnosis & \multicolumn{1}{c}{ Remarks } \\
\hline PC & 7 & $9.47 / 1.425$ & PC & None \\
& 16 & $7.035 / 0.309$ & PC & Hypertension \\
BPH & 28 & $5.14 / 0.69$ & BPH & Hypertension \\
& 46 & $7.29 / 0.63$ & BPH & None \\
\hline
\end{tabular}

$\mathrm{PC}$, prostate cancer; $\mathrm{BPH}$, benign prostatic hyperplasia.

(acrylamide: bisacrylamide $=37.5: 1 ; \mathrm{w} / \mathrm{v}$ ) gels in $1 \mathrm{X}$ TAE buffer with $200 \mathrm{ng}$ of each PCR product. A denaturing gradient of 40-60\% was applied in the DGGE electrophoresis, formed with deionized formamide and urea. Gels were electrophorised in $1 \mathrm{X}$ TAE buffer at $60^{\circ} \mathrm{C}$ and $200 \mathrm{~V}$ for $3.5 \mathrm{~h}$. Subsequently, the gels were washed with ultrapure water and stained with $5 \%$ GoldView ${ }^{\mathrm{TM}}$ dye for $30 \mathrm{~min}$ and photographed. DGGE graphs were digitized by Quantity One Analysis software (Gene Genius; Syngene, Frederick, MD, USA).

DGGE band sequencing. Selected DGGE bands (2 and 4) were cut with a sterile surgical blade under UV and purified with DNA Gel Extraction kit (SK1135; Sangon). Purified DNA was then amplified again with the primers described earlier. PCR products were ligated into the pUCm-T vector and transformed into competent $E$. coli $\mathrm{DH} 5 \alpha$ cells (both from Sangon). Recombinant cells were selected and inoculated into the fluid medium that was loaded with antibiotic ampicillin and were cultured overnight at $37^{\circ} \mathrm{C}$. Subsequently, bacteria were collected and DNA with the plasmid was extracted using a UNIQ-10 column kit (Sangon) as per the manufacturer's protocol. Clones that migrated to the same position as the original DGGE bands were sequenced (Sangon).

Obtained sequences were searched online based on the NCBI GenBank database (http://www.ncbi.nlm.nih.gov) BLAST to identify the closest relative for the partial $16 \mathrm{~S}$ rRNA gene. The same sequences were identified when the similarity of the sequence was $>97 \%$. Based on the BLAST results, reference sequences of phylogenetic neighbor species (up to $97 \%$ similarity) were included for construction of the phylogenetic tree using the MEGA 5 software package, ver. 5.05, according to the method of neighbor-joining based on evolutionary distances. The consistency of the tree was validated by bootstrapping $(n=1,000)$.

\section{Results}

PCR efficiency detection. Patient characteristics are provided in Table I. PSA analysis was performed before prostate biopsy. The total DNA of each biopsy tissue was successfully extracted and the amplified fragments of PCR were 230 bp (Fig. 1). Based on the results obtained, it is evident that 16s RNA gene fragments of bacteria in the specimens had good amplification efficiency.

DGGE analysis and sequencing results. DGGE fingerprinting with primer pair F341-GC and R534, amplified the total 

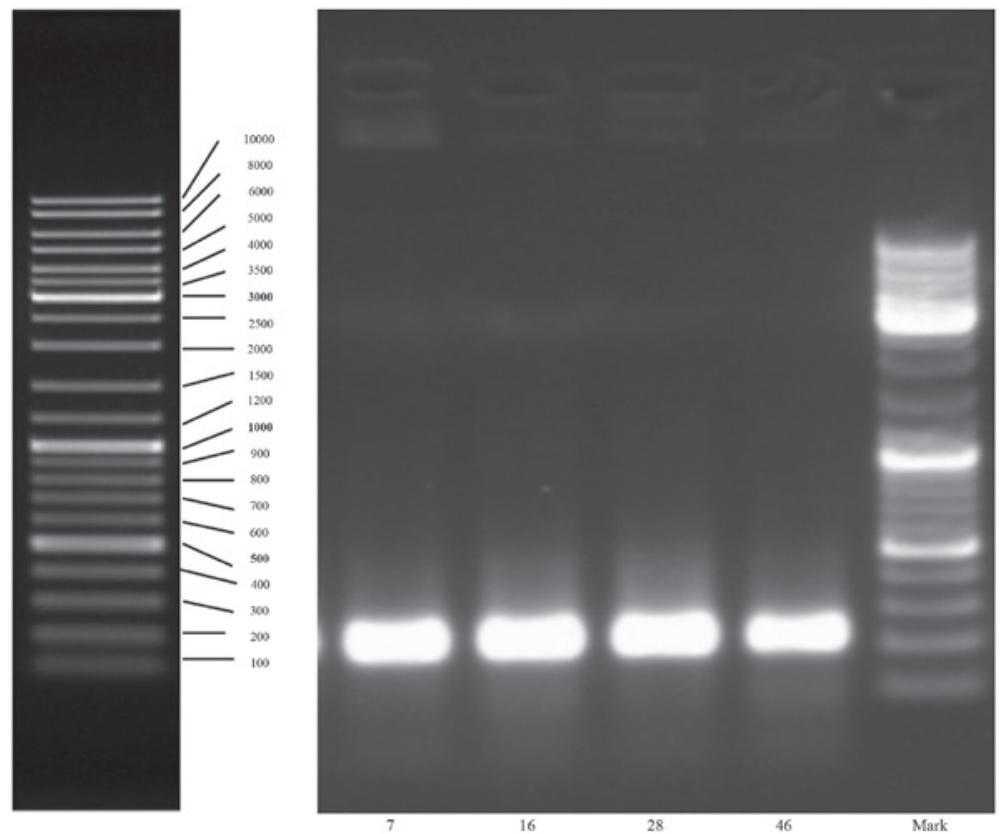

Figure 1. Gel profiles of the V3 region amplified by PCR from the DNA extracted from the patients of prostate biopsy of the BPH and PC groups. Fragment lengths were $\sim 230 \mathrm{bp}$. PCR, polymerase chain reaction; $\mathrm{BPH}$, benign prostatic hyperplasia; PC, prostate cancer.

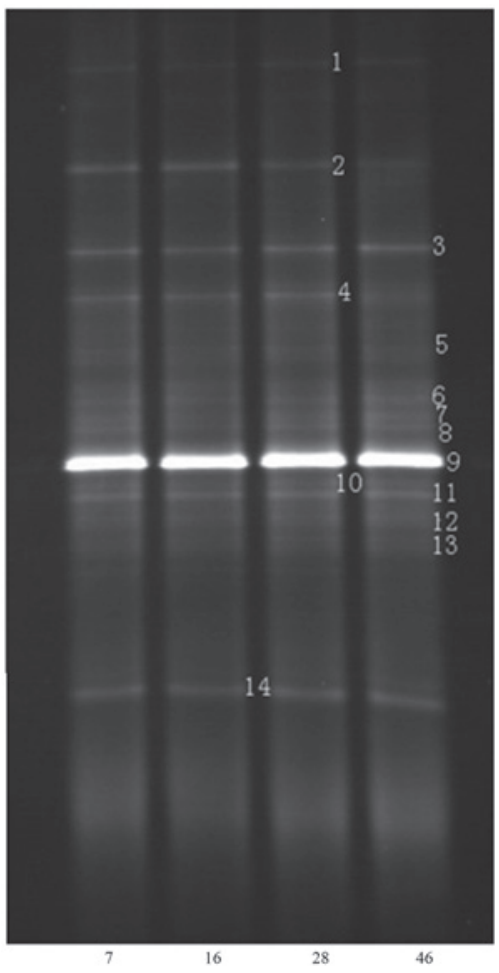

Figure 2. DGGE. Gel profiles of the V3 region amplified by PCR from the DNA extracted from the patients of prostate biopsy of BPH and PC groups. Lane 7, BPH; lane 16, BPH with hypertension; lane 28, PC with hypertension; lane 46, PC. DGCE, denaturing gradient gel electrophoresis; PCR, polymerase chain reaction; $\mathrm{BPH}$, benign prostatic hyperplasia; $\mathrm{PC}$, prostate cancer.

microbial community. The results were presented with separated bands of different DNA sequences (Fig. 2) and there were 14 discernible bands. According to the DGGE profile, band 2 and 4 were selected for sequencing since there was obvious difference between the hypertension and non-hypertension groups. The two bands were amplified again and the lengths of fragments were $\sim 180 \mathrm{bp}$. The amplification results are shown in Fig. 3. Sequences of selected bands 2 and 4 both matched that of Sphingomonas (Fig. 4). The result showed that presence of Sphingomonas was less in PC patients without hypertension compared with PC patients with hypertension.

\section{Discussion}

At present, many microorganisms cannot be cultivated under the most refined conditions (19), and most bacteria in existence do not multiply on conventional media according to environmental studies (20-22). Due to difficult cloning or the lack of a cloning technique and sequencing of $16 \mathrm{~S}$ products, very few $16 \mathrm{~S}$ sequences from prostate tissue of PC patients have been reported. Species belonging to the bacterial family Enterobacteriaceae (and specifically sequences related to E. coli) appear to be the most commonly detected organism at present (23).

The advent of molecular-based methods for identifying and characterizing microorganisms has led to a new era of microbial discovery. The 16S rDNA-based techniques have been proven to be more substantially sensitive and accurate than traditional techniques that depend on microbial culture $(11,12)$. Several studies have evaluated the presence of multiple and diverse bacterial $16 \mathrm{~S}$ rDNA sequences in prostate biopsy tissue from BPH and PC patients (15,24-26). In the present study, we used PCR-DGGE with 16S rDNA finger printing analysis to investigate bacterial composition in the biopsy of PC patients in the PSA grey-zone with or without hypertension.

Comprehending the composition and richness of the microbial ecosystem in the prostate biopsy tissue which is related to prostate health is essential for understanding the cause of prostate diseases, as well as for determining its prevention and treatment. Exploring the effect of hypertension 

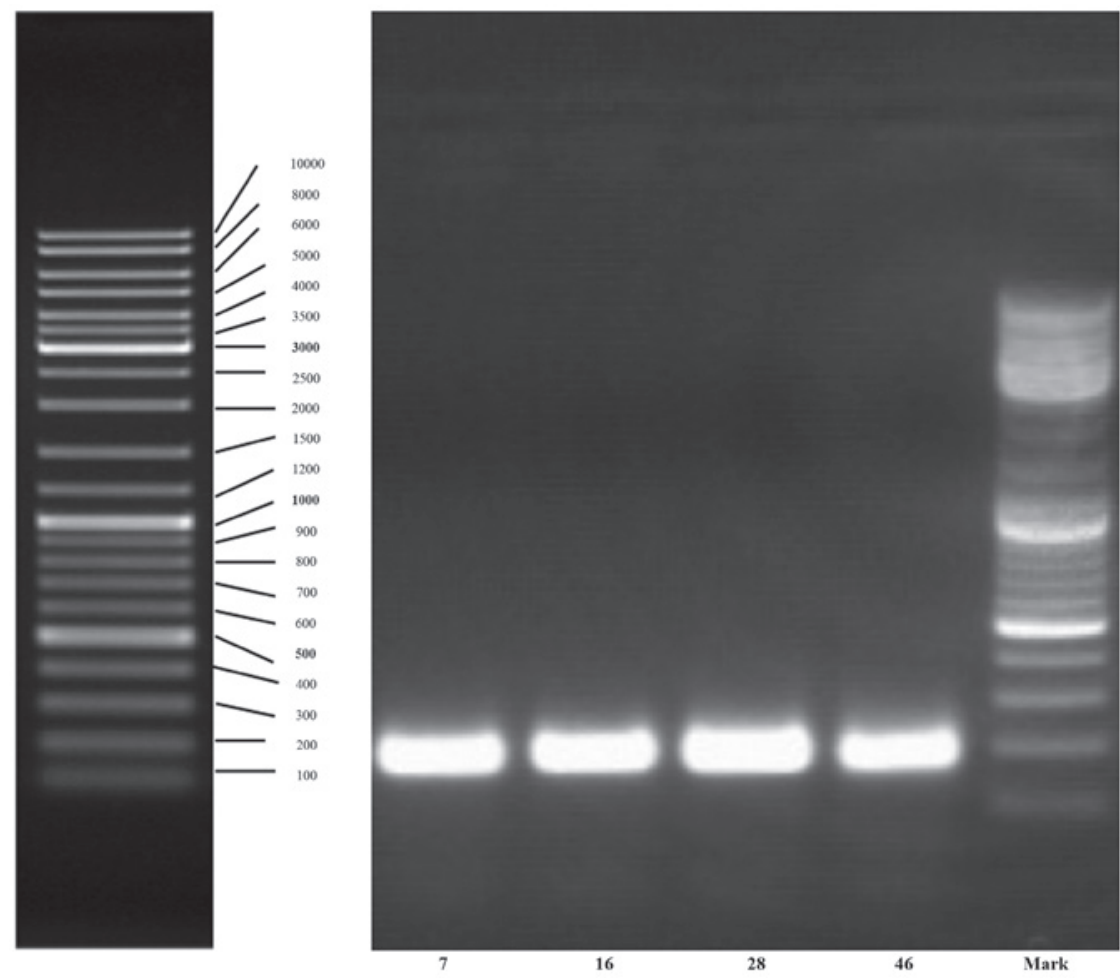

Figure 3. Gel profiles of the V3 region amplified by PCR from bands 2 and 4. Fragment lengths were $\sim 180 \mathrm{bp}$. PCR, polymerase chain reaction.

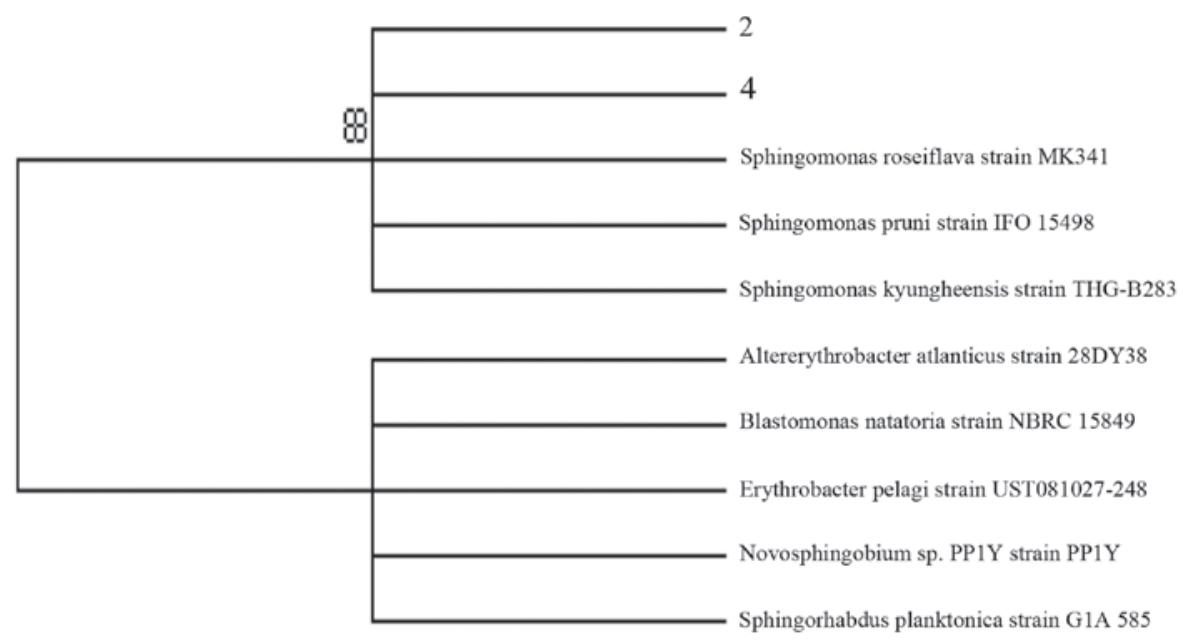

Figure 4. Phylogenetic tree of band 2 and 4

on the prostate patients and detection of bacteria in prostate tissue may be useful to make an important step in determining the etiology of these syndromes (27).

According to a statistical analysis based on the clinical data and the PCR-DGGE profiles, the structure of the bacterial community differed in the PC group. Two bands were identified as the key variable factors for the discrepancy of BPH and PC patients. This proved that the Sphingomonas were greater in BPH than PC. The Sphingomonas is a group of gram-negative bacteria that belongs to the Alphaproteobacteria which is one of the most common strains involved in urinary tract infection. It is likely that bacteria in the male reproductive tract and urethra may approach prostate tissue, thus its analysis may more likely reflect shift in the type of bacterial presence in the prostate with different diseases. We found that Sphingomonas in PC patients with hypertension was greater than that in PC patients without hypertension, and there was no difference between $\mathrm{BPH}$ and $\mathrm{PC}$ with hypertension. Therefore, hypertension has become a factor that affects diagnosis of PC in grey-zone.

The sequencing results showed that particular types of bacteria exist in the prostate biopsy tissue and these bacteria were not usually detected in other parts of the human body. We can predict that the ecological balance of microenvironment in the prostate biopsy tissue may be important in the manifestation of BPH and PC. More studies should be performed to detect any opportunistic, pathogenic bacteria in BPH and PC, to investigate the potential molecular and cellular mechanisms 
underpinning the protective effect of the commensal bacterial and the destructive mechanism of the pathogenic bacteria.

In addition, common diseases such as hypertension should be considered in the diagnosis in order to increase accuracy in the future. Such studies should include many more patients with BPH and PC with other comorbidity. Bacterial composition from $\mathrm{BPH}$ and $\mathrm{PC}$ biopsy tissues may provide further confidence in a broad-spectrum PCR approach due to its efficiency and less time-consumption.

In conclusion, Sphingomonas was present in lower amounts in PC without hypertension when compared to PC with hypertension. The result may be significant for revealing the relationship between hypertension with PC.

\section{Acknowledgements}

The present study was funded by a grant from the Medicine and Health Science and Technology Plan Projects of Zhejiang Province (2012RCA022).

\section{References}

1. Ferlay J, Steliarova-Foucher E, Lortet-Tieulent J, Rosso S, Coebergh JW, Comber H, Forman D and Bray F: Cancer incidence and mortality patterns in Europe: estimates for 40 countries in 2012. Eur J Cancer 49: 1374-1403, 2013.

2. National Cancer Institute: What you need to know about TM prostate cancer. http://www.cancer.gov/cancertopics. Accessed September 25, 2014.

3. Lim SS, Vos T, Flaxman AD, Danaei G, Shibuya K, Adair-Rohani H, Amann M, Anderson HR, Andrews KG, Aryee $\mathrm{M}$, et al: A comparative risk assessment of burden of disease and injury attributable to 67 risk factors and risk factor clusters in 21 regions, 1990-2010: a systematic analysis for the Global Burden of Disease Study 2010. Lancet 380: 2224-2260, 2012.

4. Kyrou I, Chrousos GP and Tsigos C: Stress, visceral obesity, and metabolic complications. Ann N Y Acad Sci 1083: 77-110, 2006.

5. Beebe-Dimmer JL, Dunn RL, Sarma AV, Montie JE and Cooney KA: Features of the metabolic syndrome and prostate cancer in African-American men. Cancer 109: 875-881, 2007.

6. Han JH, Choi NY, Bang SH, Kwon OJ, Jin YW, Myung SC, Chang IH, Kim TH and Ahn SH: Relationship between serum prostate-specific antigen levels and components of metabolic syndrome in healthy men. Urology 72: 749-754, discussion 754-755, 2008

7. Takeshita K, Takahashi S, Tang M, Seeni A, Asamoto M and Shirai T: Hypertension is positively associated with prostate cancer development in the TRAP transgenic rat model. Pathol Int 61: 202-209, 2011.

8. Yu H, Meng H, Zhou F, Ni X, Shen S and Das UN: Urinary microbiota in patients with prostate cancer and benign prostatic hyperplasia. Arch Med Sci 11: 385-394, 2015.

9. Handschur M, Pinar G, Gallist B, Lubitz W and Haslberger AG: Culture free DGGE and cloning based monitoring of changes in bacterial communities of salad due to processing. Food Chem Toxicol 43: 1595-1605, 2005.
10. Vartoukian SR, Palmer RM and Wade WG: Strategies for culture of 'unculturable' bacteria. FEMS Microbiol Lett 309: 1-7, 2010.

11. Clarridge JE III: Impact of $16 \mathrm{~S}$ rRNA gene sequence analysis for identification of bacteria on clinical microbiology and infectious diseases. Clin Microbiol Rev 17: 840-862, 2004.

12. Harris KA and Hartley JC: Development of broad-range $16 \mathrm{~S}$ rDNA PCR for use in the routine diagnostic clinical microbiology service. J Med Microbiol 52: 685-691, 2003.

13. Maidak BL, Cole JR, Parker CT Jr, Garrity GM, Larsen N, Li B, Lilburn TG, McCaughey MJ, Olsen GJ, Overbeek R, et al: A new version of the RDP (Ribosomal Database Project). Nucleic Acids Res 27: 171-173, 1999.

14. Ranjard L, Poly F and Nazaret S: Monitoring complex bacterial communities using culture-independent molecular techniques: Application to soil environment. Res Microbiol 151: 167-177, 2000.

15. Leskinen MJ, Rantakokko-Jalava K, Manninen R, Leppilahti M, Marttila T, Kylmälä T and Tammela TL: Negative bacterial polymerase chain reaction (PCR) findings in prostate tissue from patients with symptoms of chronic pelvic pain syndrome (CPPS) and localized prostate cancer. Prostate 55: 105-110, 2003.

16. Liu SJ, Chen GQ, Ye HY and Wang XF: Detection and significance of $16 \mathrm{~S}$ rDNA in the prostatic secretions of patients with chronic prostatitis. Zhonghua Nan Ke Xue 12: 413-415, 2006 (In Chinese).

17. Shannon BA, Cohen RJ and Garrett KL: Influence of 16S rDNA primer sequence mismatches on the spectrum of bacterial genera detected in prostate tissue by universal eubacterial PCR. Prostate 68: 1487-1491, 2008

18. Mahenthiralingam E, Baldwin A, Drevinek P, Vanlaere E, Vandamme P, LiPuma JJ and Dowson CG: Multilocus sequence typing breathes life into a microbial metagenome. PLoS One 1: e17, 2006.

19. Amann R, Springer N, Ludwig W, Görtz HD and Schleifer KH: Identification in situ and phylogeny of uncultured bacterial endosymbionts. Nature 351: 161-164, 1991.

20. Lane DJ, Pace B, Olsen GJ, Stahl DA, Sogin ML and Pace NR: Rapid determination of $16 \mathrm{~S}$ ribosomal RNA sequences for phylogenetic analyses. Proc Natl Acad Sci USA 82: 6955-6959, 1985.

21. Ward DM, Weller R and Bateson MM: 16S rRNA sequences reveal uncultured inhabitants of a well-studied thermal community. FEMS Microbiol Rev 6: 105-115, 1990.

22. Wilson KH: Detection of culture-resistant bacterial pathogens by amplification and sequencing of ribosomal DNA. Clin Infect Dis 18: 958-962, 1994

23. Sfanos KS, Sauvageot J, Fedor HL, Dick JD, De Marzo AM and Isaacs WB: A molecular analysis of prokaryotic and viral DNA sequences in prostate tissue from patients with prostate cancer indicates the presence of multiple and diverse microorganisms. Prostate 68: 306-320, 2008.

24. Hochreiter WW, Duncan JL and Schaeffer AJ: Evaluation of the bacterial flora of the prostate using a 16S rRNA gene based polymerase chain reaction. J Urol 163: 127-130, 2000.

25. Keay S, Zhang CO, Baldwin BR and Alexander RB: Polymerase chain reaction amplification of bacterial 16s rRNA genes in prostate biopsies from men without chronic prostatitis. Urology 53: 487-491, 1999.

26. Krieger JN, Riley DE, Vesella RL, Miner DC, Ross SO and Lange PH: Bacterial DNA sequences in prostate tissue from patients with prostate cancer and chronic prostatitis. J Urol 164: 1221-1228, 2000.

27. Krieger JN, Riley DE, Roberts MC and Berger RE: Prokaryotic DNA sequences in patients with chronic idiopathic prostatitis. J Clin Microbiol 34: 3120-3128, 1996. 